\title{
CHAIRMAN'S MESSAGE TO THE BRITISH ASSOCIATION OF SPORT AND MEDICINE
}

\section{Dear Member,}

Although there may not have been much sign of activity to the general membership, a great deal has been happening over the last year which will be of interest to BASM members.

First the Society of Apothecaries has agreed to proceed with setting up a Diploma Examination in Sports Medicine. The Society of Apothecaries have been taking a close interest in the activities of BASM and the London Sports Medicine Institute which has just started a three year parttime training course in Sports Medicine for London General Practitioners. The Apothecaries run several post-graduate medical Diploma examinations in fields such as Industrial Medicine and Forensic Medicine and expressed an interest in Sports Medicine. Mr. John King, Dr. Peter Sperryn and myself met a group of Apothecaries and discussed the need for such a Diploma examination. I was subsequently asked to address their examination committee and, when they were won over, submitted additional evidence to the main "Court" who have now agreed. The curriculum and conditions of entry have yet to be discussed and settled, but at last there will be a medical qualification in Sports Medicine in this country that a busy General Practitioner can study for on a part-time basis.

The corollary to this is that, on behalf of BASM, I have submitted a major grant application to the Sports Council for an education officer to be based at the London Sports Medicine Institute. This would mean that the training courses and educational material produced at the LSMI could be made available and used as core material for courses organised outside London, so that GPs outside London could benefit from what is going on at the LSMI. The initial grant submission was presented to the Sports Council in late January, and redrafted with their help in July and submitted in its final form in August and a decision is due in late November. $£ 250,000$ has been allocated from the Sports Council budget for sports medicine and sports science so I find it difficult to conceive that our grant application will not be successful.

Those of you who are not GPs may question the relevance to them. The answer is that official recognition of the importance of sports medicine within the medical establishment is essential before we can raise the general standard in Britain. There is already a post-graduate course for physiotherapists organised by the ACPSM and the major criticism of the sportsman has always been that his GP is not interested in his problems. We hope that this will now change.

There has been some criticism from the Regions of the new constitution and "all the money going to London". Recognition as a Company and a Charity is dependent on centralised accounting and accountability. The executive has agreed that up to $25 \%$ of subscription money can be remitted to a Region to pay for local activity so those of you who complain that nothing happens in BASM should be organising local meetings.
The journal would welcome this submission of more clinical papers concerned with sports medicine. Recent bias towards sports science reflects the emphasis of the manuscripts which the Editors receive, so those of you who complain about the content of the journal should be writing papers to remedy the situation. The Editors will be espousing the developing educational role of BASM and hope to publish review papers which help to cover the curriculum of the new Apothecaries Diploma whilst also being relevant and interesting to all the membership.

BASM will retain its multidisciplinary structure and role but must recruit a larger membership, particularly of doctors and medical students. Much smaller European countries have much larger medical membership of their equivalent organisations and now we have solved some of our organisational problems we must strengthen BASM by increasing its membership. Recruitment within Regions is obviously important, but anyone in BASM who wants to set up sports-based interest groups (such as cycling, tennis, swimming, sculling, etc.) is welcome to do so and our new computerised database can be used to put them in touch with people of similar interests.

Finally, can I recruit some runners? The Dutch Medical Joggers Association is organising a medical marathon on 2 September, 1989 and wish to make it a major medical event with a medical conference, $10 \mathrm{~km}$ run, half marathon and marathon. Anyone interested please send me a stamped addressed envelope c/o The London Sports Medicine Institute, The Medical College of St. Bartholomew's Hospital, London EC1M 6BO. I will then send you further details as I receive them myself. The entry criteria have not yet been decided but there will probably be different categories, doctors, physiotherapists, scientists, etc.

Finally I hope you will all seriously consider the form of the new Executive. We need new blood in the Executive which is now decidedly middle-aged. I was asked to Chair BASM and agreed to try to get it on its feet. I have seen it through its new constitution, have set up the London Sports Medicine Institute with a 5 year Grant from the GLC and have now been instrumental in getting Sports Medicine a Post-Graduate Diploma for doctors. My role as Director of the London Sports Medicine Institute has been to further Sports Medicine in several directions, but has been confusing for some of the membership of BASM and I should now be devoting more energy to fund-raising for the LSMI so that this base for academic sports medicine in Britain is not lost.

I hope BASM will now prosper but it will only do so with a young and vigorous membership and Executive and we therefore need members willing to take on the considerable work involved.

Dan Tunstall Pedoe, Chairman November 1987 